\title{
ASTRONOMERS INDEX
}

Āryabhata (b.476), 17,78, $86,89,94,97,101-102,104,106$, $197-201$.

Abd al-Munim-al-Āmilīi,215, 216. Abi- $\bar{i}-R i j \bar{a} 1$ 's, 175 .

Abü Abd Allāh Muhammad ibn Abī Bakr Al-Farisī, 203.

Abū Muhammad Atā b. Ahmad, 179 .

Abū Nasr ibn Irāq (10th cent. ), 212 .

Abü'l-Wafa' (9 40-998), 209,210. Abu'l-Husayn al-Súfí (d.986),156. Abu-Mac Shar, 154.

al-Battānì al-Sābì $(858-929), 175,209$.

al-Bīrūnì $(973-1048), 133,144$.

al-Bițūjōi (twelfth century), 178 .

al-Fahhād, 204 .

al-Hajjāg, 157 .

al-Käshi (fl.1420),144.

Al-Khwārizmi (d.860),176.

al-Marzūqi (d 1030),154.

al-Qàyiní ( 10 th century),216.

al-Qazwinid (d 1283),154.

al-Shi rāzí, 204 .

al-Shi rwānìi, 204.

al-CUrdī (1260), 216,222.

al-Zarqālluh, 175,179.

Aluel ben Yeshac,203.

Amaghavajra (705-774), 125 .

Anaxagoras, 65 .

Anaximander, 65-66.

Anaximenes, 66 .

Apollonius of Perga, 70 .

Archimedes, 69 .

Aristarchos of Samos,209.

Ari starchus, 69 .

Aristotle, 65-66, ,208.

Aristyllus, 69 .

Autolycus, $66,67,209$.

Bahā'uddín al- ${ }^{C} \bar{A} m i l i \bar{i}$

(1547-1622), 217 .

Bahrām ibn Binyāmin,205.

Barhebraeus (d.1286),156.

Berossus Babylonian priest, 115 .

Bhāskara I (c.600),89.

Bhāskara II (1150),86.
Bhad rabāhu (contemporary of Varāhamihira), 110 .

Bhattotpala (10th Century), 110.

Brahmaguptā (628),82,86.

Abd al-Jabbār al-Kharaqī,204.

Caliph Mansūr (754-775) of Baghdad ,139 .

Callippus, 67 .

Copernicus, $69,209,273$.

De Bois, 235 .

De La Hire,236.

Edmond Halley $(1686), 111,256$.

Eratosthenes, 69 .

Euclid (fl.ca. 295 B.C.) 65,210 .

Eudoxus (ca. 400-347 B.C), 67 .

Fakhr al-Dīn Gurgānì

(a round 1050),155.

Father Christoph,261.

Flamsteed,236.

Galileo Galelei,261.

Galileo,261 .

Gaṇeśa Daivajña (b. 1507),193.

Geminus, 72 .

Hipparchus, 70,72,209.

Hypsicles, 70 .

Ibn Asim (d.1013),154.

-al-Ajdābì ( d. prior

to 1203$), 154$.

-ash-Shatir,273.

-Qutayba (d.884 or 889),154.

-Sìda (d.1066), 154 .

-Yansi', 205.

-Yünus', 178 .

Issac ben Sid, 178 .

Jabir ibn Aflah,238.

Jesuit Matteo Ricci (1552-1610), 38 .

Johannes Fabricius,261.

-Kepler (1571-1630),261,265.

John of London (1246),155-156.

Kāshī (fl. 1420),185.

Kidenas (Babylonian ast ronomer), 70 .

-Lunar tables, 70.

Kukai (806) the founder of the Shingon School of

Tantric Buddhism, 125 .

Lāṭadeva (505),86.

Lagadha ( $f 1$. ca. sixth century B.C. ), 22 . 
Lalla ( 748$), 86,102,105$.

Linconus Roger (1250), 157 .

Mādhava of Sańgamagrāma (c.1460-1425), 198 .

Mahend ra sūri,191.

Menelaos, 209.

Mohmud bin,204.

Muhd. Bāqar Yazdī, 219.

Muñks̄la (932),86.

Muníśsara (b. A.D.1603), 193 .

Nașīr al-Dīn al-Ṭūsì $(1201-1274), 180,185,188$, 209,210 .

Newcomb , 256 .

Nỉlakantha Somayāji (1444-1545), 22,81.

Padmanābha, 191-195.

Parameśvara (1380-1460),80.

Pauliśa, 17 .

Plato (427-347 B.C.) ,34,67.

Ptolemaos, 209 .

Ptolemy, 17, 70-73,139,154,222, 276,237 .

Putumana Somayājīi, 79 .

Pythagoras (ca. 582-500 B.C.) ,34,

Qāsim ${ }_{\text {Alì Qàyini, }}^{67-68}$ 216.

Qāsim bin Mutarraf,205.

Qutb al-Dín al-Shírāzí,204.
Qutrub (d.after 825),156.

Regiomontanus $(1436-1476), 209$.

Sa'id al-Andalusì (eleventh century), 178 .

Śañkara Vāriar (1500-60),81.

Sawai Jai Singh (d.1743),233.

Sima Quian,36.

Sphujīdhvaja,133.

Sripati (1039),86.

Sudines (Babylonian astronomer), 70 .

Taqī al-Dīn of

$$
\text { Istanbul, } 209 \text {. }
$$

Thäbit ibn Qurra (836-901),177.

Timocharis, 69 .

Tycho, 265.

Ulugh Beg (1393-1449),6,211,233 .

Varahamihira (d.587),

Vaśișţha, 17 .

$$
100-101,109,111 \text {. }
$$

Vasubandhu, 133 .

Vateśvara (904),86.

Vettius Vatens $(\sim 160), 86$.

Vi jayanand in, 102,142 .

Vi șucand ra (200), 140 .

Yahà ibn Abī Mansür, 205.

Yang Ching-fenz (764),126. 